\title{
Prediction of Bankruptcy Using Financial Ratios in the Greek Market
}

\author{
George Giannopoulos*, Sindre Sigbjørnsen \\ Kingston Business School, Kingston University, London, UK \\ Email: ^g.giannopoulos@kingston.ac.uk
}

How to cite this paper: Giannopoulos, G. and Sigbjørnsen, S. (2019) Prediction of Bankruptcy Using Financial Ratios in the Greek Market. Theoretical Economics Letters, 9, 1114-1128.

https://doi.org/10.4236/tel.2019.94072

Received: February 18, 2019

Accepted: April 26, 2019

Published: April 29, 2019

Copyright $\odot 2019$ by author(s) and Scientific Research Publishing Inc. This work is licensed under the Creative Commons Attribution International License (CC BY 4.0).

http://creativecommons.org/licenses/by/4.0/

\begin{abstract}
This study explores the forecasting ability of bankruptcy prediction models for firms listed on the Athens Stock Exchange. The models have been tested whether they are able to predict bankruptcy one, two and three years prior bankruptcy. The highest bankruptcy predictive accuracy is achieved by the Taffler's and Grammatikos and Gloubos' $Y$ models. Early and accurate sign of bankruptcy helps businesses take necessary actions to solve financial distress; hence the Greek bankruptcy prediction models will help companies minimize risk.
\end{abstract}

\section{Keywords}

Bankruptcy, Financial Ratios, Forecasting Ability, Prediction Models

\section{Introduction}

The research objective of this study is to determine the most accurate bankruptcy prediction model that can be used to predict insolvency of industrialized firms in the Greek market. To do so, this study examines six different well-established bankruptcy prediction models: Altman's [1] Z-score model, Taffler's [2] model, Grammatikos and Gloubos [3] $X$ and $Y$ models, Zopounidis and Doumpos [4] model and Dimitras et al. [5] model. These models are used to predict bankruptcy in firms listed on the Athens Stock Exchange. The sample period of this research is between 2002 and 2012. This study examines the practical application of the aforementioned models by estimating their coefficients using a logit regression framework. The $80 \%$ of the sample observations is used to estimate the coefficients of the models and the remaining $20 \%$ of the observations (the holdout sample) is used to test the accuracy of the models.

The global financial crisis of 2008 had a severe impact on several countries 
and Greece is among those affected the hardest. In 2018, Greece comes to the end of its eighth year of external financial assistance, but it has a long way to go on the road to recovery. Greek output is now 3.7 per cent higher than in mid-2015, which makes it 25 per cent below 2007 levels $^{1}$. The European Union has several times interfered and bailed the country out of its on-going economic turmoil [6]. O'Brien [7] reports that the Athens Stock Exchange has fallen over $600 \%$ since its peak in November 2007, this makes the fall worse than the fall during the Great Depression in 1933. Numerous Greek companies went bankrupt post-2007 and several pre-bankruptcy procedures have been introduced [8]. According to IMF's 2018 annual health check of the Greek economy: "Greece has successfully eliminated its extraordinarily high fiscal and current account deficits, and restored growth. It must now take action to address crisis legacies and boost inclusive growth"2.

An early and accurate sign of bankruptcy can help businesses take necessary actions to solve financial distress. Applying the aforementioned bankruptcy prediction models to the Greek market will potentially help companies in Greece minimize risk and avoid bankruptcy in the future.

There is a substantial research on bankruptcy prediction models, but the majority of these have been created before the economic crisis of 2007. Therefore, using a more recent (after the financial crisis) sample period (2002-2012) of 50 companies listed on the Athens Stock Exchange, we estimate the aforementioned models and check whether their predictive accuracy is affected. Safeguarding a valid bankruptcy prediction model is valuable for the Greek capital market. This study may be useful for many internal and external stakeholders such as management, employees, customers, banks, investors and other creditors. In particular, it may assist the managers of corporations to take drastic measures to avoid bankruptcy, it may help employees and customers to identify and associate themselves with companies with low insolvency risk, and it may help banks and investors to allocate capital more efficiently.

The remainder of this study is structured as follows: Section 2 critically evaluates previous literature on corporate bankruptcy studies. Section 3 describes the data collection process and the methodology used in this study; in particular it presents the different models that have been used in the research to predict bankruptcy. Section 4 describes the models with the estimated coefficients for the Greek market. Section 5 analyses the findings, whereas Section 6 concludes the paper and discusses potential areas for future research.

\section{Literature Review}

Altman [9] stated that four different terms has been used when discussing financial distress in companies: failure, solvency, bankruptcy and default. A common term of financial distress is when a company "cannot meet its current obligation" [9]. When this occurs a company normally increases its loans to meet its pay-

${ }^{1}$ See for example Financial Times: https://www.ft.com/content/3067bf9c-8a88-11e8-bf9e-8771d5404543. ${ }^{2}$ Source, International Monetary Fund: www.imf.org/en/News/Articles/2018/07/30/NA07302018. 
ments. But, when a firm misses scheduled loan and/or bond payments, a legal default is an option, which results in filing for bankruptcy.

Financial distress cost is classified as either direct or indirect. Direct costs are considered out-of-pocket expenses for accountants, turnaround specialists, lawyers, expert witnesses and other professionals. Indirect costs are all unobservable opportunity costs. These costs include all loss of sales and profits by customers for choosing not to go into business with a company that is entering bankruptcy [9].

Hunter and Isachenkova [10] argue that company distress and company failure is because of their inability to pay debts as they come due. Reasons as to why companies are unable to pay their bills are associated with gearing and insufficiency of liquid assets.

Poston et al. [11] present five stages of business failure. The stages are; the incubation stage, the financial embarrassment stage, the financial insolvency stage, the total insolvency stage and finally the confirmed insolvency stage. The first stage will most likely go unnoticed by the company; this is the stage when the financial difficulties are developing. In the second stage, the management and probably others in the company will note the difficulties that the company is suffering from. This is the stage where the company is unable to meet their payments, even though the company have assets that exceed their liabilities. Even though the company have the assets, the assets that the company has is not possible to use for payments as they are not liquidated.

The third stage of business failure, the financial insolvency stage, is when the firm is unable to obtain necessary funds to pay its obligations. From this stage there is still firms that are restored to a healthy state. However, the firms which are not able to return to a healthy state progress to stage four: total insolvency stage. According to Fitspatrick [12] cited in Poston et al. [11] the fourth stage occurs when the liabilities exceed the physical assets. It is, in a number of instances, the time when the general public and those creditors not yet apprised of the firm's true condition first learn that the company is failing. The business can no longer avoid the confession of failure.

At the fourth stage, the total insolvency stage, creditors may take over the business or restructure the troubled debt. The company may also make an attempt to get extra funds from financing sources. If none of these are successful, the business enters the confirmed insolvency stage, the last/fifth stage. This step includes legal steps to protect the firm's creditors. As mentioned, this is when the company files for bankruptcy. The majority of companies that reaches this final step are liquidated, but some companies are returned to a healthy state through restructuring and reorganization.

The general definition of failure is when a company is not able to pay their lenders, suppliers, preferred stock shareholders and so on, a bill is overdrawn, or the firm is bankrupt according to law. All these situations previously mentioned terminate the firms operations [5]. 
Taffler [2] states that there are financial indicators or symptoms that can be analysed to predict bankruptcy/corporate failures. The symptoms or indicators can be observed by looking at the financial results of the company over a period of time; e.g. see Slatter (1984) and Hunter and Isachenkova [10].

Altman [1] stated that financial ratios can be used to detect if a company is having operating and financial difficulties. The usage of financial ratios to check the status of the companies' profitability, liquidity, leverage, turnover, variability and size gives the viewer a good understanding of the company [13]. In Beaver's [14] research of financial ratios figured out that by using financial ratios give signs of financial distress about five years prior to bankruptcy.

Throughout the years there have been several different studies that have used different ratios for predicting bankruptcy. According to Bellovary et al. [15] bankruptcy prediction literature dates back to the 1930s. The Bureau of Business Research published in 1930 a study in which 8 ratios determined that gave a good indicator of failing firms. The next 30 years bankruptcy prediction models used univariate or single factor analysis to predict future bankruptcy. Using individual ratios for predicting bankruptcy can be misleading and inadequate. Altman [1] was the first research to publish a multivariate discriminate analysis model. Altman's Z-score model uses five financial ratios to calculate a Z-score, which differentiates a healthy company with an unhealthy company.

In addition to Altman's Z-score model, there were two other models that were developed during the 1960s. After 1960 several other models have been developed. 28 studies were published in the 1970s, 53 studies were published in the 1980 s and 70 studies were published in the 1990s. In the period $2000-2004$ there were 11 studies that were published [15]. These studies are on different research area and therefore different number of ratios is included in the models. Ohlsen [16] developed a logit analysis, Zmijewski (1984) developed probit analysis in the study. Other models that have been developed are Altman et al. [9] neural networks, Vermeulen et al. (1998) multi-factor model and Messier and Hansen (1988) expert system model. Auditors, bond analysts, insurance companies, banks, and financial institutions make use of such models; i.e. see Poston et al. [11] and Dimitras et al. [5].

The models that have been developed use several different ratios to predict company bankruptcy. Compared to Altman's Z-score which uses five different ratios to analyse company bankruptcy Jo et al. [17] uses as many as 57 different ratios in their multivariate discriminant analysis. The more ratios the model use, does not necessary means higher accuracy of the model. For example Jo, Han and Lee's [17] model is $81.94 \%$ accurate, while Rose and Kolari [18] model that uses 23 different ratios is 76\% accurate and Moses and Liao [19] model which uses three different ratios is $85 \%$ accurate. Table 1 provides detailed information for the competing models.

The models that have been developed have been created for several different sectors; manufacturing firms, banks, airline companies, small firms, oil and gas companies and so on. Additionally, the models have been developed for specific 
Table 1. Information for the competing models.

\begin{tabular}{|c|c|c|c|c|}
\hline & Application Study Period & Criteria for failed firm & Timeframe & Model Accuracy \\
\hline Altman model & $\begin{array}{l}33 \text { failed and } 33 \text { non-failed US } \\
\text { manufacturing firms 1946-1965 }\end{array}$ & $\begin{array}{l}\text { Firm that filed a bankruptcy petition under } \\
\text { Chapter X of the National Bankruptcy Act }\end{array}$ & 5 years & $76 \%$ for hold-out sample \\
\hline Taffler model & $\begin{array}{l}23 \text { Failed and } 45 \text { non-failed UK } \\
\text { industrial firms, 1968-1973 }\end{array}$ & $\begin{array}{l}\text { Receivership, voluntary liquidation, } \\
\text { winding up by court order or equivalent }\end{array}$ & 4 years & $\begin{array}{l}96 \% \text { for failed firms and } 100 \% \\
\text { for non-failed firms }\end{array}$ \\
\hline $\begin{array}{l}\text { Grammatikos and } \\
\text { Gloubos } X \text { model }\end{array}$ & $\begin{array}{l}29 \text { failed Greek industrial firms } \\
\text { and } 29 \text { non-failed firms, } 1977-1981\end{array}$ & Went bankrupt or applied for bankruptcy & 3 years & $\begin{array}{l}93 \% \text { for failed firms and } 90 \% \\
\text { for non-failed firms }\end{array}$ \\
\hline $\begin{array}{l}\text { Grammatikos and } \\
\text { Gloubos } Y \text { model }\end{array}$ & $\begin{array}{l}29 \text { failed Greek industrial firms } \\
\text { and } 29 \text { non-failed firms, 1977-1981 }\end{array}$ & Went bankrupt or applied for bankruptcy. & 3 years & $\begin{array}{l}90 \% \text { for failed firms and } 93 \% \\
\text { for non-failed firms. }\end{array}$ \\
\hline Dimitras et al. model & $\begin{array}{l}80 \text { Greek firms, } 40 \text { failed firms and } \\
40 \text { non-failed firms, } 1986-1990\end{array}$ & Went bankrupt or applied for bankruptcy. & 3 years & $\begin{array}{l}\text { Hold-out sample: Year } 1: \\
\text { Failed firms: } 63.2 \% \\
\text { Healthy firms: } 68.4 \%\end{array}$ \\
\hline $\begin{array}{l}\text { Zopounidis and } \\
\text { Doumpos model }\end{array}$ & 58 Failed and 58 non-failed firms. & Failed firms. & 3 years & $\begin{array}{l}\text { Hold-out sample Year-1: } 65.79 \% \\
\text { Year-2: } 57.89 \% \\
\text { Year-3: } 55.26 \%\end{array}$ \\
\hline
\end{tabular}

countries; Gloubos and Grammatikos [3] were developed a model for Greek firms, Taffler [2] were focused on UK manufacturing firms while Rose and Kolari [18] were predicted bankruptcy in banks. Other models were developed for general application, such as Karels and Prakash (1987).

Even though the vast majority of the literature of bankruptcy prediction has focused the research on the US and the UK, there are also models that have been developed for Greek firms. Gloubos and Grammatikos [3] focused their research on Greek firms and created a set of linear probability, probit, logit and multi discriminate analysis models. The most accurate of the developed models were the probit and the linear probability models which both had a 70.8\% accuracy. Theodossiou [20] created a linear probability model, a logit model and a probit model for Greek manufacturing firms. The most accurate of these models was the linear probability model which had a 96.4\% accuracy. Dimitras et al. [5] [21] created three different models for Greek firms, a rough set theory model, a multi discriminate analysis model and a logit model, of these the rough set theory model was the most accurate with $73.7 \%$ accuracy one-year prior bankruptcy. Zopounidis and Doumpos [4] created a utilities additives discriminant model, which used twelve different ratios with accuracy varying from $47.37 \%$ to $84.21 \%$ for bankrupt companies. The models discussed in this section have been developed and used before the financial crisis of 2007. The present study tests whether the multi discriminate analysis models perform well on a more recent (after the 2007 financial crisis) sample period. Therefore the following two hypotheses are investigated:

Hypothesis (1): Bankruptcy of Greek companies can be predicted using financial ratios.

Under this hypothesis it is investigated whether bankruptcy in the Greek market can be predicted by analysing the ratios of different companies. 
Hypothesis (2): Altman's Z-score model [1] gives a better bankruptcy prediction of Greek companies compared to other models.

\section{Data Collection and Existing Models}

The data collected from DataStream ${ }^{\mathrm{TM}}$ are the public records from the Athens Stock Exchange, including data from their: balance sheet, income statement and the cash flow statement. The data have been collected for 25 bankrupt companies for the period 2002-2012. To check if the models can differentiate between healthy and unhealthy companies 25 healthy companies have also been chosen. The healthy companies have been matched to the bankrupt companies regarding size and industry. Only companies with a full data set are included in the sample. The models' predictive accuracy is tested one, two and three years prior to bankruptcy. Table 2 provides information about the financial ratios employed in various studies.

According to Burns and Burns [22] a discriminant analysis model is a linear equation that will divide the results into two groups, in this case bankrupt and non-bankrupt. The different combination of the variables provides a score for each company using the generic formula:

$$
Z_{i}=v_{0}+\sum_{j=1}^{N} v_{j} x_{j, i}+\varepsilon_{i} .
$$

where $Z_{i}$ is the discriminant function, or the score that divides the samples into groups, $v_{j}$ are the coefficients, $x_{j, i}$ are the scores for the different variables, $v_{0}$ is a constant coefficient, $N$ is the number of explanatory variables, and $\varepsilon_{i} \sim N\left(0, \sigma_{\varepsilon}^{2}\right)$. To differentiate between bankrupt and non-bankrupt companies a cut-off score is calculated. Based on this cut-off score and the Z-score of the company, a firm is classified as bankrupt or non-bankrupt. To differentiate between bankrupt and non-bankrupt companies the distribution of the scores is essential. If the scores overlap each other as illustrated in Figure 1, it will be hard to differentiate between bankrupt and non-bankrupt companies. However if the distribution is like the bottom figure, misclassification is minimal.

The six multiple discriminant analysis models that have been established in literature are investigated: Altman's [1] Z-score, Taffler's [2], Grammatikos and Gloubos's [3], Dimitras' et al. [5] and Zoupounidis and Doumpos's [4] models.

$$
\begin{aligned}
& \text { Altman's } Z \text {-score } \\
& \qquad Z_{i}=0.12 x_{1, i}+0.14 x_{2, i}+0.033 x_{3, i}+0.006 x_{4, i}+0.999 x_{5, i}+\varepsilon_{i},
\end{aligned}
$$

where $Z_{i}$ denotes the overall index, $x_{1, i}$ is the working capital to total assets, $x_{2, i}$ are the retained earnings to total assets, $x_{3, i}$ are the earnings before interest and tax (EBIT) to total assets, $x_{4, i}$ is the market capitalisation to total liabilities, whereas $x_{5, i}$ denote the sales to total assets. The cut-off score for this model is 2675 . If the Z-score is lower than 2675 the company is a bankrupt company. If the $\mathrm{Z}$-score is above 2675 then the company is a non-bankrupt company.

Taffler's Model

$$
Z_{i}=3.2+12.18 x_{1, i}+2.5 x_{2, i}-10.68 x_{3, i}+0.029 x_{4, i}+\varepsilon_{i},
$$


Table 2. Information for the financial ratios employed.

\begin{tabular}{|c|c|c|c|c|c|c|}
\hline Financial Ratios & Altman [1] & Taffler [24] & $\begin{array}{c}\text { Grammatikos } \\
\text { and Gloubos [3] } \\
\text { XModel }\end{array}$ & $\begin{array}{c}\text { Grammatikos } \\
\text { and Gloubos } \\
\text { [4] YModel }\end{array}$ & $\begin{array}{c}\text { Dimitras et al. } \\
{[5]}\end{array}$ & $\begin{array}{c}\text { Zopounidis and } \\
\text { Doumpos [4] }\end{array}$ \\
\hline \multicolumn{7}{|l|}{ Profitability } \\
\hline EBIT/Total assets & $\mathrm{X}$ & & & & $\mathrm{X}$ & $\mathrm{X}$ \\
\hline Profit before tax/Current Liabilities & & $\mathrm{X}$ & $\mathrm{X}$ & $\mathrm{X}$ & & \\
\hline Earnings after Tax to Current Liabilities & & & $\mathrm{X}$ & $\mathrm{X}$ & & \\
\hline Net Income to Gross Profit & & & & & $\mathrm{X}$ & $\mathrm{X}$ \\
\hline Net income to Total Assets & & & & & $\mathrm{X}$ & $\mathrm{X}$ \\
\hline \multicolumn{7}{|l|}{ Liquidity } \\
\hline Working Capital/Total Assets & $\mathrm{X}$ & & $\mathrm{X}$ & $\mathrm{X}$ & & \\
\hline Current Assets/Total Liabilities & & $\mathrm{X}$ & & & $\mathrm{X}$ & $\mathrm{X}$ \\
\hline Current liabilities to current assets & & $\mathrm{X}$ & & & & \\
\hline Current Assets to Total Assets & & & $\mathrm{X}$ & & & \\
\hline Notes payable to total assets & & & $\mathrm{X}$ & & & \\
\hline Quick Assets to Current Liabilities & & & & & $\mathrm{X}$ & $\mathrm{X}$ \\
\hline Current Liabilities To Total Assets & & & & & $\mathrm{X}$ & $\mathrm{X}$ \\
\hline \multicolumn{7}{|l|}{ Leverage } \\
\hline Equity Market Value to Total Liabilities & $\mathrm{X}$ & & & & & \\
\hline Retained Earnings/Total Assets & $\mathrm{X}$ & & & & & \\
\hline Net worth to Net worth + Long term debt & & & & & $\mathrm{X}$ & $\mathrm{X}$ \\
\hline (Long term debt + current liabilities) to total assets & & & & & $\mathrm{X}$ & $\mathrm{X}$ \\
\hline Net worth to Net fixed assets & & & & & $\mathrm{X}$ & $\mathrm{X}$ \\
\hline \multicolumn{7}{|l|}{ Turnover } \\
\hline Sales/Total Asset & $\mathrm{X}$ & & & & & \\
\hline No-credit interval in days & & $\mathrm{X}$ & & & & \\
\hline Inventories/Net working Capital & & & $\mathrm{X}$ & & $\mathrm{X}$ & $\mathrm{X}$ \\
\hline Net Income to Total Worth & & & & & $\mathrm{X}$ & $\mathrm{X}$ \\
\hline Working capital to net worth & & & & & $\mathrm{X}$ & $\mathrm{X}$ \\
\hline
\end{tabular}

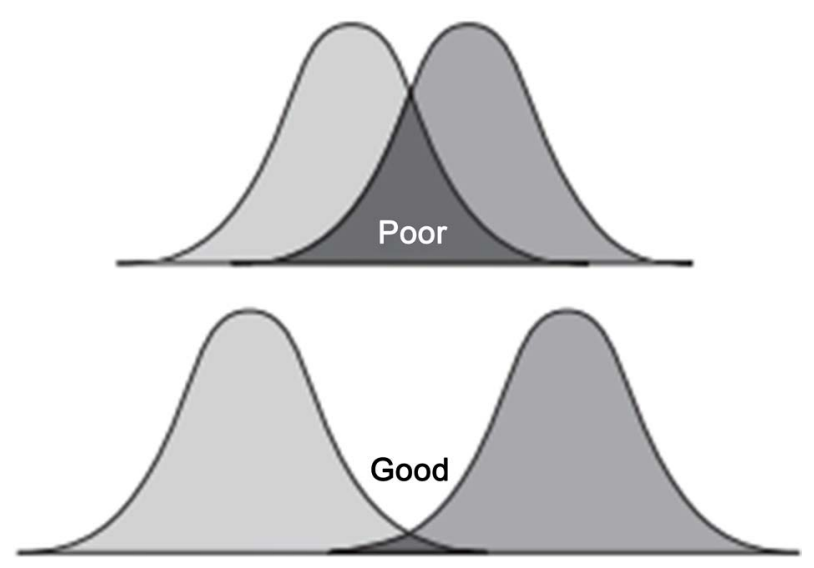

Figure 1. The distribution of the scores [22]. 
where $Z_{i}$ is the overall index, $x_{1, i}$ is the profit before tax to current liabilities, $x_{2, i}$ denote the current assets to total liabilities, $x_{3, i}$ are the current liabilities to current assets, $x_{4, i}$ expresses the no-credit interval in days (liquid current assets/daily cash operating expenses) or (quick assets - current liabilities)/((sales profit before tax)/365). In this model the cut-off score is -1.95 . If the $\mathrm{Z}$ score is lower then -1.95 the company is a bankrupt company. If the $\mathrm{Z}$ score is above -1.95 the company is a non-bankrupt company. The ratio $x_{4, i}$ is the estimated time that a company could finance the expenses of its business with the company's current level of activity [23].

\section{Grammatikos and Gloubos' Model}

Grammatikos and Gloubos presented two different models, one with six ratios ( $X$ model) and one with three ratios ( $Y$ model), therefore two sets of coefficients have been created for the ratios.

$$
\begin{aligned}
Z_{i}= & -0.863-2.461 x_{1, i}+5.33 x_{2, i}-0.022 x_{3, i}+3.676 x_{4, i} \\
& +3.543 x_{5, i}+4.223 x_{6, i}+\varepsilon_{i}
\end{aligned}
$$

where $Z_{i}=$ overall $\mathrm{X}$ score, $x_{1, i}=$ current assets to total assets, $x_{2, i}=$ net working capital to total assets, $x_{3, i}=$ inventories to net working capital, $x_{4, i}=$ notes payable to total assets, $x_{5, i}=$ earnings after taxes to current liabilities, $x_{6, i}=$ gross income to total assets. The cut-off score of this model is 0 . If the $\mathrm{Z}$ score is below 0 the company is a bankrupt company. If the $\mathrm{Z}$ score is over 0 the company is a non-bankrupt company.

$$
Y_{i}=0.313+0.546 x_{2, i}+0.805 x_{5, i}+0.979 x_{6, i}+\varepsilon_{i},
$$

where $Y_{i}$ is the overall Y-score. The cut-off score of this model is 0.5 . If the Y score is below 0.5 the company is a bankrupt company, otherwise it is a non-bankrupt company.

\section{Dimitras et al.'s Model}

$$
\begin{aligned}
Z_{i}= & -1.151+0.0093 x_{1, i}+1.9154 x_{2, i}+2.4196 x_{3, i}+0.1245 x_{4, i} \\
& +1.2882 x_{5, i}-0.9008 x_{6, i}-0.7149 x_{7, i}+0.004 x_{8, i}+0.0342 x_{9, i} \\
& -0.0168 x_{10, i}+0.6294 x_{11, i}+0.0022 x_{12, i}+\varepsilon_{i}
\end{aligned}
$$

where $x_{1, i}=$ Net income to gross profit, $x_{2, i}=$ Gross profit to total assets, $x_{3, i}$ $=$ Net income to total assets, $x_{4, i}=$ Net income to total worth, $x_{5, i}=$ Current assets to current liabilities, $x_{6, i}=$ Quick assets to current liabilities, $x_{7, i}=$ (Long term debt + current liabilities) to total assets, $x_{8, i}=$ Net worth to net worth+long term debt, $x_{9, i}=$ Net worth to net fixed assets, $x_{10, i}=$ Inventories to working capital, $x_{11, i}=$ Current liabilities to total assets, $x_{12, i}=$ Working capital to net worth. The cut-off score for this model is 0.5 . If the Z-score is lower (higher) than 0.5 the company is a bankrupt (non-bankrupt) company.

\section{Zopounidis and Doumpos' Model}

$$
\begin{aligned}
U_{i}^{c 1}(a)= & 0.0523 x_{1, i}+0.0079 x_{2, i}+0.8531 x_{3, i}+0.0068 x_{4, i} \\
& +0.0079 x_{5, i}+0.0079 x_{6, i}+0.0281 x_{7, i}+0.005 x_{8, i} \\
& +0.0079 x_{9, i}+0.0079 x_{10, i}+0.0079 x_{11, i}+0.0073 x_{12, i}+\varepsilon_{i}
\end{aligned}
$$


and

$$
\begin{aligned}
U_{i}^{-c 1}(a)= & 0.0079 x_{1, i}+0.0079 x_{2, i}+0.0385 x_{3, i}+0.0068 x_{4, i} \\
& +0.0079 x_{5, i}+0.0079 x_{6, i}+0.8865 x_{7, i}+0.005 x_{8, i} \\
& +0.0085 x_{9, i}+0.0079 x_{10, i}+0.0079 x_{11, i}+0.0073 x_{12, i}+\varepsilon_{i}
\end{aligned}
$$

where $x_{j, i}$, for $j=1, \cdots, 12$, are the same with Equation (6). Instead of the cut-off score this model compares two different scores. If $U_{i}^{c 1}(a)>U_{i}^{-c 1}(a)$ the company is non-bankrupt company, otherwise the company is a bankrupt company.

\section{Prediction of Bankruptcy in the Greek Market}

This study uses the logit regression framework to estimate the models' coefficients based on the $80 \%$ of the observations ${ }^{3}$ (the basic sample). The predictive ability of the models with the updated coefficients is tested on the $20 \%$ holdout sample. The logit model divides the results into two groups, but instead of a cut-off score it provides a probability score. The companies' ratios of the basic sample were used to estimate the coefficients for the models. The holdout sample is used to check the accuracy of the updated models. The probability scores have been estimated based on the logistic regression presented in Burns and Burns [22]:

$$
P\left(d_{t}=1 \backslash x_{j, i}\right)=1-\Phi\left(-v_{0}-\sum_{j=1}^{N} v_{j} x_{j, i}\right),
$$

where $\Phi($.$) is the cumulative distribution function for the logistic distribuion,$ $d_{t}=1$ denotes the status of a non-bankrupt company, whereas $d_{t}=0$ the status of a bankrupt company, $P\left(d_{t}=1\right)$ is the probability that a case is in a particular category (i.e. $\left.d_{t}=1\right), v_{j}$ are parameters to be estimated and $x_{j, i}$ define the scores of the various ratios. The models with the updated coefficients are listed in the lines follow:

$$
\begin{aligned}
& \text { Altman's } Z \text {-score } \\
& \qquad P\left(d_{t}=1 \backslash x_{j, i}\right)=1-\Phi\left(-3.84 x_{1, i}-0.78 x_{2, i}-12.21 x_{3, i}+0.46 x_{4, i}-0.63 x_{5, i}\right) .
\end{aligned}
$$

In the original model the cut-off score was 2675 , while in the updated model the Z-score is converted into probability as the probability scores are between 0 and 1 . If the probability is higher than 0.5 the model predicts that this company will survive. If the probability is lower than 0.5 the model predicts that this company will not survive.

Taffler's ModeI ${ }^{4}$

$$
P\left(d_{t}=1 \backslash x_{j, i}\right)=1-\Phi\left(-4.02 x_{1, i}-0.27 x_{2, i}+0.46 x_{3, i}-123.9 x_{4, i}\right) .
$$

\section{Grammatikos and Gloubos' Models}

$X$ model

$$
\begin{aligned}
& P\left(d_{t}=1 \backslash x_{j, i}\right) \\
& =1-\Phi\left(5.26 x_{1, i}-4.35 x_{2, i}-1.52 x_{3, i}-4.82 x_{4, i}-1.74 x_{5, i}-8.38 x_{6, i}\right)
\end{aligned}
$$

${ }^{3}$ Both logit and probit techniques provide quite similar estimation outputs. The advantage of logit modelling is that its coefficients can be interpreted in terms of odds ratios, whereas the advantage of probit model is its ability to account for non-constant error variances.

${ }^{4}$ The re-estimated model does not include a constant term compared to the original model. 
$Y$ model

$$
P\left(d_{t}=1 \backslash x_{j, i}\right)=1-\Phi\left(-3.93 x_{2, i}-1.18 x_{5, i}-2.44 x_{6, i}\right) .
$$

\section{Dimitras et al.'s-Zopounidis and Doumpos Models ${ }^{5}$}

Dimitras et al., employ the same ratios with Zopounidis and Doumpos, therefore one model is re-estimated.

$$
\begin{aligned}
P\left(d_{t}=1 \backslash x_{j, i}\right)= & 1-\Phi\left(-1.20 x_{1, i}+6.47 x_{2, i}-89.14 x_{3, i}+9.24 x_{4, i}\right. \\
& -5.21 x_{5, i}+14.59 x_{6, i}-30.04 x_{7, i}-0.32 x_{8, i} \\
& \left.-0.19 x_{9, i}-0.69 x_{10, i}+19.63 x_{11, i}-3.03 x_{12, i}\right)
\end{aligned}
$$

\section{Analysis of the Findings}

Table 3 explains the presentation format of the models' predictive accuracy results. "Type 0" denotes the bankrupt companies. If the model shows the company as bankrupt the prediction is correct. If the model classifies the company as a non-bankrupt company we have a "Type 0 error". "Type 1" denotes the nonbankrupt companies. As with Type 0 , the classification is correct if the model classifies the company as a non-bankrupt company. If on the other hand the model classifies the non-bankrupt company as a bankrupt company we have a Type 1 error. The last line shows the sum of both Type 0 companies and Type 1 companies. This adds up the correct and the incorrect percentage score and gives an overall score, in other words both bankrupt and non-bankrupt companies have been taken into consideration in the final line.

A summary of the predictive ability of the different models is presented in Table 4. Initially Altman's model results are presented. One year prior bankruptcy in the basic sample when considering only bankrupt companies the prediction accuracy is $73.69 \%$ and for the non-bankrupt companies the correct classification increases to $90 \%$. The overall accuracy is $82.05 \%$. In the holdout sample the accuracy decreases to $40 \%$ when considering only bankrupt companies but it increases to $100 \%$ for the non-bankrupt companies making the overall accuracy $70 \%$.

Two-years prior bankruptcy, the overall accuracy is $62 \%$ in the basic sample. When considering only bankrupt companies the accuracy is $47.37 \%$, and for non-bankrupt companies the accuracy is $75 \%$.

Three-years prior bankruptcy the overall accuracy of the basic sample declines to $55.88 \%$. Considering only non-bankrupt companies the accuracy is $88.24 \%$. In

Table 3. Explanation of the results.

\begin{tabular}{ccc}
\hline 1 year prior & \% of Correct & \% of Incorrect \\
\hline Type 0 & $\mathrm{XX} \%$ & $\mathrm{XX} \%$ \\
Type 1 & $\mathrm{XX} \%$ & $\mathrm{XX} \%$ \\
Total & $\mathrm{XX} \%$ & $\mathrm{XX} \%$ \\
\hline
\end{tabular}

${ }^{5}$ The coefficients are statistically significant at $5 \%$ level. 
Table 4. Predictive accuracy.

\begin{tabular}{|c|c|c|c|c|c|c|}
\hline \multirow[b]{2}{*}{ Altman Basic } & \multicolumn{2}{|c|}{$1 \mathrm{yr}$} & \multicolumn{2}{|c|}{$2 \mathrm{yr}$} & \multicolumn{2}{|c|}{$3 \mathrm{yr}$} \\
\hline & Correct & Incorrect & Correct & Incorrect & Correct & Incorrect \\
\hline Type 0 & $73.68 \%$ & $26.32 \%$ & $47.37 \%$ & $52.63 \%$ & $23.53 \%$ & $76.47 \%$ \\
\hline Type 1 & $90.00 \%$ & $10.00 \%$ & $75.00 \%$ & $25.00 \%$ & $88.24 \%$ & $11.76 \%$ \\
\hline Total & $82.05 \%$ & $17.95 \%$ & $62.00 \%$ & $38.00 \%$ & $55.88 \%$ & $44.12 \%$ \\
\hline \multicolumn{7}{|l|}{ Holdout } \\
\hline Type 0 & $40.00 \%$ & $60.00 \%$ & $20.00 \%$ & $80.00 \%$ & $0.00 \%$ & $100.00 \%$ \\
\hline Type 1 & $100.00 \%$ & $0.00 \%$ & $100.00 \%$ & $0.00 \%$ & $100.00 \%$ & $0.00 \%$ \\
\hline Total & $70.00 \%$ & $30.00 \%$ & $60.00 \%$ & $40.00 \%$ & $50.00 \%$ & $50.00 \%$ \\
\hline Taffler Basic & Correct & Incorrect & Correct & Incorrect & Correct & Incorrect \\
\hline Type 0 & $84.21 \%$ & $15.79 \%$ & $68.42 \%$ & $31.58 \%$ & $42.11 \%$ & $57.89 \%$ \\
\hline Type 1 & $85.00 \%$ & $15.00 \%$ & $75.00 \%$ & $25.00 \%$ & $75.00 \%$ & $25.00 \%$ \\
\hline Total & $84.62 \%$ & $15.38 \%$ & $71.79 \%$ & $28.21 \%$ & $58.97 \%$ & $41.03 \%$ \\
\hline \multicolumn{7}{|l|}{ Holdout } \\
\hline Type 0 & $80.00 \%$ & $20.00 \%$ & $40.00 \%$ & $60.00 \%$ & $0.00 \%$ & $100.00 \%$ \\
\hline Type 1 & $80.00 \%$ & $20.00 \%$ & $100.00 \%$ & $0.00 \%$ & $80.00 \%$ & $20.00 \%$ \\
\hline Total & $80.00 \%$ & $20.00 \%$ & $70.00 \%$ & $30.00 \%$ & $40.00 \%$ & $60.00 \%$ \\
\hline GG X Basic & Correct & Incorrect & Correct & Incorrect & Correct & Incorrect \\
\hline Type 0 & $84.21 \%$ & $15.79 \%$ & $72.22 \%$ & $27.78 \%$ & $35.29 \%$ & $64.71 \%$ \\
\hline Type 1 & $80.00 \%$ & $20.00 \%$ & $68.42 \%$ & $31.58 \%$ & $77.78 \%$ & $22.22 \%$ \\
\hline Total & $82.05 \%$ & $17.95 \%$ & $70.27 \%$ & $29.73 \%$ & $57.14 \%$ & $42.86 \%$ \\
\hline \multicolumn{7}{|l|}{ Holdout } \\
\hline Type 0 & $60.00 \%$ & $40.00 \%$ & $40.00 \%$ & $60.00 \%$ & $50.00 \%$ & $50.00 \%$ \\
\hline Type 1 & $80.00 \%$ & $20.00 \%$ & $40.00 \%$ & $60.00 \%$ & $80.00 \%$ & $20.00 \%$ \\
\hline Total & $70.00 \%$ & $30.00 \%$ & $40.00 \%$ & $60.00 \%$ & $66.67 \%$ & $33.33 \%$ \\
\hline GG Y Basic & Correct & Incorrect & Correct & Incorrect & Correct & Incorrect \\
\hline Type 0 & $63.16 \%$ & $36.84 \%$ & $50.00 \%$ & $50.00 \%$ & $17.65 \%$ & $82.35 \%$ \\
\hline Type 1 & $90.00 \%$ & $10.00 \%$ & $84.21 \%$ & $15.79 \%$ & $83.33 \%$ & $16.67 \%$ \\
\hline Total & $76.92 \%$ & $23.08 \%$ & $67.57 \%$ & $32.43 \%$ & $51.43 \%$ & $48.57 \%$ \\
\hline \multicolumn{7}{|l|}{ Holdout } \\
\hline Type 0 & $60.00 \%$ & $40.00 \%$ & $0.00 \%$ & $100.00 \%$ & $0.00 \%$ & $100.00 \%$ \\
\hline Type 1 & $100.00 \%$ & $0.00 \%$ & $80.00 \%$ & $20.00 \%$ & $100.00 \%$ & $0.00 \%$ \\
\hline Total & $80.00 \%$ & $20.00 \%$ & $40.00 \%$ & $60.00 \%$ & $55.56 \%$ & $44.44 \%$ \\
\hline DSSZ Basic & Correct & Incorrect & Correct & Incorrect & Correct & Incorrect \\
\hline Type 0 & $89.47 \%$ & $10.53 \%$ & $52.63 \%$ & $47.37 \%$ & $63.16 \%$ & $36.84 \%$ \\
\hline Type 1 & $90.00 \%$ & $10.00 \%$ & $85.00 \%$ & $15.00 \%$ & $70.00 \%$ & $30.00 \%$ \\
\hline Total & $89.74 \%$ & $10.26 \%$ & $69.23 \%$ & $30.77 \%$ & $66.67 \%$ & $33.33 \%$ \\
\hline \multicolumn{7}{|l|}{ Holdout } \\
\hline Type 0 & $60.00 \%$ & $40.00 \%$ & $40.00 \%$ & $60.00 \%$ & $20.00 \%$ & $80.00 \%$ \\
\hline Type 1 & $80.00 \%$ & $20.00 \%$ & $80.00 \%$ & $20.00 \%$ & $60.00 \%$ & $40.00 \%$ \\
\hline Total & $70.00 \%$ & $30.00 \%$ & $60.00 \%$ & $40.00 \%$ & $40.00 \%$ & $60.00 \%$ \\
\hline
\end{tabular}


the holdout sample the overall accuracy declines to $50 \%$.

Using Taffler model one year prior bankruptcy the overall accuracy is $84.62 \%$ in the basic sample and $80 \%$ in the holdout sample. In the holdout sample the correct classification for both bankrupt and non-bankrupt companies is the same (80\%). The overall accuracy of the holdout sample is therefore, $80 \%$, which is the highest predictive accuracy of all the models when focusing on the holdout sample.

Two-years prior bankruptcy the overall accuracy is $70 \%$ in the holdout sample. Considering only bankrupt companies the accuracy is $40 \%$ and for the non-bankrupt companies the correct classification is $100 \%$.

Three-years prior bankruptcy the overall accuracy declines to $58.97 \%$ in the basic sample. In the holdout sample the overall predicting accuracy declines further to $40 \%$.

Regarding Grammatikos and Gloubo's $X$ model the accuracy in the basic sample when considering only bankrupt companies is $84.21 \%$ one year prior bankruptcy. Considering only non-bankrupt companies the accuracy is $80 \%$ making the overall accuracy for the basic sample $82.05 \%$. In the holdout sample the accuracy when considering only bankrupt companies is $60 \%$ and $80 \%$ when considering only non-bankrupt companies making the overall accuracy $70 \%$.

Two-years prior bankruptcy the accuracy is $72.22 \%$ when considering only bankrupt companies in the basic sample. For non-bankrupt companies the accuracy is $68.42 \%$. The overall accuracy two-years prior bankruptcy in the basic sample is $70.27 \%$. In the holdout sample the accuracy is $60 \%$ when considering only bankrupt companies, $60 \%$ when considering only non-bankrupt companies making the overall accuracy of the holdout sample two-years prior bankruptcy $60 \%$.

Three-years prior bankruptcy the accuracy declines further to $35.29 \%$ in the basic sample when considering only bankrupt companies and $77.78 \%$ considering only non-bankrupt companies. The overall accuracy is $57.14 \%$ three-years prior bankruptcy in the basic sample. In the holdout sample the accuracy is $50 \%$ when considering only bankrupt companies and $80 \%$ when considering only non-bankrupt companies. The overall accuracy of the holdout sample is $66.67 \%$.

Concerning Grammatikos and Gloubo's $Y$ model, one-year prior bankruptcy the accuracy is $63.16 \%$ when considering only bankrupt companies in the basic sample and $90 \%$ considering only non-bankrupt companies. The overall accuracy one-year prior bankruptcy in the basic sample is $76.92 \%$. The holdout sample has a higher overall accuracy with $80 \%$. The accuracy when considering separately bankrupt and non-bankrupt companies is $60 \%$ and $100 \%$, respectively.

Two-years prior bankruptcy the accuracy of the model when considering only bankrupt companies is $50 \%$, in the basic sample. For non-bankrupt companies the accuracy is $84.21 \%$. The overall accuracy of the basic sample is therefore $67.57 \%$. The overall accuracy for the holdout sample two-years prior bankruptcy is $40 \%$. Three-years prior bankruptcy the overall accuracy in the basic sample is $51.43 \%$. The overall accuracy in the holdout sample is $66.67 \%$. 
Regarding the common model framework of Dimitras et al. and Zopounidis and Doumpos the overall accuracy is $89.74 \%$ in the basic sample one year prior bankruptcy. This consists of $89.47 \%$ accuracy when considering only bankrupt companies and $90 \%$ when considering only non-bankrupt companies. In the holdout sample the accuracy of the model is $70 \%$.

Two-years prior bankruptcy the accuracy declines to $69.23 \%$ in the basic sample and to $60 \%$ in the holdout sample. Three-years prior bankruptcy the accuracy in the basic sample is $66.67 \%$ and declines further to $40 \%$ in the holdout sample.

Overall these results suggest that bankruptcy can be predicted with an accuracy range between $70 \%-90 \%$ one-year prior bankruptcy, $40 \%-72 \%$ two-years prior bankruptcy and $40 \%-67 \%$ three-years prior bankruptcy. These results confirm the first hypothesis which suggests that bankruptcy of Greek firms can be predicted using financial ratios.

Regarding the second hypothesis test one-year prior bankruptcy the best models to predict bankruptcy and non-bankruptcy in the holdout sample is Taffler's and Grammatikos and Gloubos' $Y$ models. Both models have an accuracy of $80 \%$. Dimitras et al. model has the highest predictive accuracy in the basic sample.

Two-year prior bankruptcy the best model for predicting bankruptcy and non-bankruptcy is again Taffler's with 70\% accuracy.

The best model three-years prior bankruptcy is Grammatikos and Gloubos' $\mathrm{X}$-model with $66.67 \%$ accuracy, in the holdout sample. Second best is the Grammatikos and Gloubos' Y-model with 55.56\% accuracy. Overall these results suggest that the second hypothesis does not hold i.e. Altman's Z-score model does not provide the highest bankruptcy prediction accuracy for Greek firms.

\section{Conclusions and Suggestions for Further Research}

The main research objective of this study is to determine the most accurate bankruptcy prediction model that can be used to predict insolvency of industrialized firms in the Greek market. This study used six different well-established bankruptcy prediction models Altman's [1] Z-score model, Taffler's [2] model, Grammatikos and Gloubos [3] $X$ and $Y$ models, Zopounidis and Doumpos [4] model and Dimitras et al. [5] model. In particular, this study investigates the practical application of these models by re-estimating their coefficients using a recent sample period (2002-2012) of 50 Greek firms. The main findings of the two hypotheses tests are the following: 1) Financial ratios and accounting information are important in predicting bankruptcy of companies on the Athens Stock Exchange and 2) Altman's [1] Z-score model is not the best predictor model of bankruptcy in Greece. The models with the best total prediction accuracy (including both bankrupt and non-bankrupt companies) are: Taffler's [2] model and Grammatikos and Gloubos'[3] $Y$ model.

Financial ratios in multi-discriminate analysis and logit models can predict bankruptcy in the Greek market with relatively high accuracy. It can be con- 
cluded that Taffler's [2] model could be used efficiently as a bankruptcy prediction tool in the Greek market to predict bankruptcy and non-bankruptcy of Greek listed firms. The accuracy of the model is as high as $80 \%$ in the holdout sample one-year prior bankruptcy. Grammatikos and Gloubos [3] $Y$ model is also a good predictor of bankruptcy and non-bankruptcy in the Greek market with $80 \%$ accuracy in the holdout sample one-year prior bankruptcy. Similarly these two models maintain high accuracy levels two and three years prior bankruptcy.

Overall this study provides empirical evidence that corporate bankruptcy in the Greek market is predictable. Taffler's [2] and Grammatikos and Gloubos' [3] $Y$ models can assist a firm's stakeholders, such as investors, lending banks, auditors to evaluate bankruptcy risk. In 2018, even though Greece comes to the end of its eighth year of external financial assistance, the impact of financial crisis is still evident i.e. high unemployment rate of $18 \%$ (even though declining from the pick of $27.5 \%$ in 2013) due to many corporate insolvencies during the turmoil period. Therefore, by providing the stakeholders with a prediction device to detect companies that are experiencing distress it may assist: i) banks and investors to allocate capital more efficiently ii) the owners and managers of the companies to take drastic measures to avoid bankruptcy iii) employees to identify and work for companies with low insolvency risk.

Future research may focus on testing the predictive accuracy of the models on specific industries, such as banks, airline companies, hospitals etc. This research study focused on companies listed in the Athens Stock Exchange. Given that many Greek non-listed small and medium enterprises (SMEs) got bankrupt it would be also interesting to test the models' accuracy on non-listed SMEs in Greece.

\section{Conflicts of Interest}

The authors declare no conflicts of interest regarding the publication of this paper.

\section{References}

[1] Altman, E.I. (1968) Financial Ratios, Discriminant Analysis and the Prediction of Corporate Bankruptcy, Journal of Finance, 23, 589-610. https://doi.org/10.2307/2978933

[2] Taffler, R.J. (1983) The Assessment of Company Solvency and Performance Using a Statistical Model, Accounting and Business Research, 13, 295-308. https://doi.org/10.1080/00014788.1983.9729767

[3] Grammatikos, T. and Gloubos, G. (1984) Predicting Bankruptcy of Industrial Firms in Greece. Spoudai, 34, 421-443.

[4] Zopounidis, C. and Doumpos, M. (2002) Multi-Group Discrimination Using Multi-Criteria Analysis: Illustrations from the Field of Finance. European Journal of Operational Research, 139, 371-389. https://doi.org/10.1016/s0377-2217(01)00360-5

[5] Dimitras, A.I., Slowinski, R., Susamaga, R. and Zopounidis, C. (1999) Business Failure 
Prediction Using Rough Sets. European Journal of Operational Research, 114, 262280. https://doi.org/10.1016/s0377-2217(98)00255-0

[6] Tokic, D. (2012) The Economic and Financial Dimensions of De-Growth. Ecological Economics, 84, 49-56. https://doi.org/10.1016/j.ecolecon.2012.09.011

[7] O’Brien, M (2012) The Greek Stock Market Has Now Fallen Over 88\%. The Atlantic, 8 May 2012.

[8] Potamitis, S. and Rokas, A. (2012) A New Pre-Bankruptcy Procedure for Greece. Journal of Business Law, 3, 235-247.

[9] Altman, E.I and Hotchkiss, E. (2011) Corporate Financial Distress and Bankruptcy: Predict and Avoid Bankruptcy, Analyze and Invest in Distressed Debt. 3rd Edition, John Wiley \& Sons, Hoboken. https://doi.org/10.1002/9781118267806

[10] Hunter, J. and Isachenkova, N. (2001) Failure Risk: A Comparative Study of UK and Russian Firms. Journal of Policy Modeling, 23, 511-521.

[11] Poston, K.M., Harmon, W.K. and Gramlich, J.D. (1994) A Test of Financial Ratios as Predictors of Turnaround versus Failure among Financially Distressed Firms. Journal of Applied Business Research, 10, 41-56. https://doi.org/10.19030/jabr.v10i1.5962

[12] Fitzpatrick, P.J. (1934) Transitional Stages of a Business Failure. The Accounting Review, 9, 337-340.

[13] Leksrisakul, P. and Evans, M. (2005) A Model of Corporate Bankruptcy in Thailand Using Multiple Discriminant Analysis. Journal Economic and Social Policy, 10, 5.

[14] Beaver, W.H. (1966) Financial Ratios as Predictors of Failure. Journal of Accounting Research, 4, 71-111.

[15] Bellovary, J.L. Giacomino, D.E. and Akers, M.D. (2007) A Review of Bankruptcy Prediction Studies: 1930 to Present. Journal of Financial Education, 33, 1-42.

[16] Ohlson, J.A. (1980) Financial Ratios and the Probabilistic Prediction of Bankruptcy. Journal of Accounting Research, 18, 109-131. https://doi.org/10.2307/2490395

[17] Jo, H., Han, I. and Lee, H. (1997) Bankruptcy Prediction Using Case-Based Reasoning, Neural Networks, and Discriminant Analysis. Expert Systems with Applications, 13, 97-108. https://doi.org/10.1016/s0957-4174(97)00011-0

[18] Rose, P. and Kolari, J. (1985) Early Warning Systems as a Monitoring Device for Bank Condition. Quarterly Journal of Business and Economics, 24, 43-60.

[19] Moses, D. and Liao, S. (1987) On Developing Models for Failure Prediction. Journal of Commercial Bank Lending, 27-38.

[20] Theodossiou, P. (1991) Alternative Models for Assessing the Financial Condition of Business in Greece. Journal of Business, Finance and Accounting, 18, 697-720. https://doi.org/10.1111/j.1468-5957.1991.tb00233.x

[21] Dimitras, A.I. Zanakis, S.H. and Zopounidis, C. (1996) A Survey of Business Failures with an Emphasis on Prediction Methods and Industrial Applications. European Journal of Operational Research, 90, 487-513. https://doi.org/10.1016/0377-2217(95)00070-4

[22] Burns, R.B. and Burns, R.A. (2008) Business Research Methods and Statistics Using SPSS. SAGE Publications Ltd., London.

[23] Graham, A. (2000) Credit Risk Management: Corporate Credit Analysis. Fitzrov Dearborn Publishers, London.

[24] Taffler, R.J. (1982) Forecasting Company Failure in the UK Using Discriminant Analysis and Financial Ratio Data. Journal of Royal Statistical Society, Series A, 145, 342-358. https://doi.org/10.2307/2981867 